\title{
Competitive and Information Effects of Cross-Border Stock Listings
}

Bruce M. Bradford

Fairfield University, bbradford@fairfield.edu

Anna D. Martin

Ann Marie Whyte

Follow this and additional works at: https://digitalcommons.fairfield.edu/business-facultypubs

Copyright 2002 Wiley for Southern Finance Association

This is the accepted version of the following article: Whyte, Ann Marie, Bruce M. Bradford, and

Anna D. Martin. "Competitive and Information Effects of Cross-Border Stock Listings." Journal of Financial Research. 25(3): 399-413, which has been published in final form athttp://onlinelibrary.wiley.com/doi/10.1111/1475-6803.00026/abstract.

\section{Peer Reviewed}

\section{Repository Citation}

Bradford, Bruce M.; Martin, Anna D.; and Whyte, Ann Marie, "Competitive and Information Effects of Cross-Border Stock Listings" (2002). Business Faculty Publications. 153.

https://digitalcommons.fairfield.edu/business-facultypubs/153

\section{Published Citation}

Whyte, Ann Marie, Bruce M. Bradford, and Anna D. Martin. "Competitive and Information Effects of Cross-Border Stock Listings." Journal of Financial Research. 25(3): 399-413

This item has been accepted for inclusion in DigitalCommons@Fairfield by an authorized administrator of DigitalCommons@Fairfield. It is brought to you by DigitalCommons@Fairfield with permission from the rightsholder(s) and is protected by copyright and/or related rights. You are free to use this item in any way that is permitted by the copyright and related rights legislation that applies to your use. For other uses, you need to obtain permission from the rights-holder(s) directly, unless additional rights are indicated by a Creative Commons license in the record and/or on the work itself. For more information, please contact digitalcommons@fairfield.edu. 


\title{
Competitive and Information Effects of Cross-Border Stock Listings
}

\author{
Bruce M. Bradford \\ Fairfield University
}

\author{
Anna D. Martin \\ Fairfield University
}

Ann Marie Whyte

University of Central Florida

JEL classification codes: G-14, G-15, F-30

Key words: Cross-border listings, information effects, competitive effects, intra-industry effects

Corresponding author: Ann Marie Whyte, Department of Finance, College of Business Administration, University of Central Florida, P.O. Box 161400, Orlando FL 32816-1400. Phone: (407) 823-3945, Fax (407) 823-6676. E-Mail: annmarie.whyte@bus.ucf.edu. 


\section{Abstract \\ Competitive and Information Effects of Cross-Border Stock Listings}

We examine the impact of 269 cross-border listings on rivals in the listing market (U.S.) and the domestic market and find that U.S. rivals experience significant gains while domestic rivals do not experience significant effects. Both competitive and information effects are important in explaining the reaction of U.S. rivals. Regarding the competitive effects, the reaction of rivals is less favorable when listings originate in developed countries and more favorable when listing firms do not have prior presence in the U.S. Regarding the information effects, the reaction is less favorable when listings are combined with equity offerings and more favorable for initial listings within the industry. 


\section{Competitive and Information Effects of Cross-Border Stock Listings}

\section{Introduction}

The globalization of financial markets has resulted in an increasing number of firms choosing to list their equities on foreign stock exchanges. Although most cross-border listings involve private non-governmental firms, the pace of listings has been accelerated by the growing trend toward global privatization. Many foreign governments have chosen to privatize companies that were previously state-owned and, in many instances, have chosen to raise capital globally by listing the newly privatized firms overseas. While there are costs, such as reporting and registration costs, associated with listing overseas, the listing can provide strategic, financial, political, marketing, and operational benefits to the firm (Karolyi (1998)). More specifically, cross-border listings can result in improved relations between the listing firm and host country market participants, improved liquidity of the firm's shares, increased investor recognition, greater prestige for the firm, and improved access to capital. In addition, an overseas listing may reduce the cost of capital by diversifying the firm's exposure to a variety of risks and reducing international investment barriers (Karolyi (1998)).

A significant number of cross-border listings have occurred on stock exchanges in the United States (U.S.). We examine the impact of these listings on industry rivals of the listing firm in both the listing market (U.S.) and the domestic market. We draw on two streams of literature in examining this issue. First, we draw on previous empirical studies that have documented that cross-border equity listings have implications for the listing firm (e.g. Alexander, Eun, and Janakiramanan (1988), Foerster and Karolyi (1993), Switzer (1997), and Foerster and Karolyi (1999)). Second, we are motivated by previous studies (e.g., Slovin, Sushka, and Polonchek (1992) and Szewczyk (1992)) that have shown that a number of events 
have implications for both the announcing firm and their industry rivals. By combining the two sets of studies, we hypothesize that cross-border listings may also have implications for both the listing firms and rival firms. As a result of the cross-border nature of this study, we examine the impact of the listing on competitors in both the listing market (U.S.) and domestic market.

Cross-border listings are likely to have a significant impact on industry rivals for two reasons. First, previous studies have shown that rival valuation effects are likely to be driven by changes in the competitive balance within the industry (e.g., Lang and Stulz (1992)). We argue that a listing may cause investors to reassess the competitive position of the listing firm relative to its rivals thus affecting the returns of rivals. Second, we build on previous studies that have explained the reaction of industry rivals to various events in terms of an information effect. Rivals may react to these events because of information embedded in the announcement that has industry-wide implications. To the extent that cross-border listings convey information that is relevant to the industry as a whole, rival firms are likely to be impacted by the listing. We identify specific factors related to both competitive and information effects and assess the importance of these factors in explaining the differential reaction of U.S. rival firms to crossborder listings.

We find that, on average, U.S. rivals experience positive and significant valuation effects surrounding the listing date. In contrast, rivals in the domestic markets do not experience significant valuation effects. Overall, the reaction by U.S. industry rivals to cross-border listings is consistent with both competitive and information effects. Regarding the competitive effects, the results suggest that U.S. rival returns are lower when the listings originate in developed countries, and more favorable for listings by firms without prior operating presence in the U.S. Regarding the information effects, the findings indicate that the returns to U.S. rivals are lower 
when stock offerings are made in conjunction with the listing and are higher for the first listing within a particular industry.

\section{Literature Review}

Previous studies provide evidence regarding the impact of foreign stock listings on the listing firm (see Karolyi (1998) for a comprehensive survey of the literature). Overall, the evidence suggests that listing firms experience positive and significant returns during the listing month. Most studies attribute this initial positive response to the benefits of diversification and to liquidity effects evidenced by increases in trading volume and an expanded shareholder base. Alexander, Eun, and Janakiramanan (1988) document a negligible reaction in the listing month for a sample of 34 firms listing in the U.S. They also document a significant decline in the listing firm's stock price in the years following the listing, and find the decline is more pronounced for non-Canadian firms relative to Canadian firms. They attribute the difference in the reaction to differences in the degree of market segmentation, arguing that the Canadian firms face fewer barriers when listing in the U.S. relative to their non-Canadian counterparts. The results presented by Forester and Karolyi (1993), however, call into question the importance of segmentation in explaining the market reaction since they find that both Canadian and nonCanadian firms experience a significant decline in their stock price following the listing. Furthermore, they find that the post-listing decline was unrelated to liquidity effects since the results were robust across the three U.S. exchanges considered. Jayaram, Shastri, and Tandon (1993) examine 95 first-time American Depositary Receipt (ADR) listings and find an insignificant market reaction during the listing month. Switzer (1997) documents large prelisting abnormal returns and shows that the reaction on the announcement date is related to the proportion of total trading volume captured by U.S. exchanges subsequent to the listing. More 
recently, Foerster and Karolyi (1999) find that non-U.S. firms cross-listing in the U.S. as ADRs earn positive and significant returns in the year prior to listing, generate positive returns of 1.2 percent during the listing week, but ultimately incur a loss of 14 percent in the year following the listing.

Overall, the evidence suggests that cross-border listings results in significant price changes for listing firms. These studies, however, focus exclusively on the impact of the listing on the listing firm. We contend that a cross-border listing may also have implications for the industry rivals of the listing firm. A number of studies have presented evidence of this type of intra-industry effect including Slovin, Sushka, and Bendeck (1991) for going-private transactions, Slovin, Sushka, and Poloncheck (1992) for stock issuance announcements, Szewczyk (1992) for security offerings, and Lang and Stulz (1992) for bankruptcy announcements. Intra-industry effects of cross-border listings may arise because of changes in the competitive balance in the industry (competitive effects), information conveyed by the listing relevant to the entire industry (information effects), or both. These arguments are explored in the next section.

\section{Testable Hypotheses}

Cross-border listings may result in competitive effects as analysts are prompted to reassess the competitive balance between the listing firms and their rivals and may also generate information effects as valuable information is transmitted about the conditions within an industry. Several variables related to these effects are described to help explain the differential response of U.S. rivals to cross-border listings. 


\section{Competitive Effects}

Cross-border listings may adversely or favorably impact the industry rivals as analysts are induced to reassess the competitive strengths and weaknesses of listing firms relative to their rivals. Foreign firms listing in the U.S. must reconcile their accounting statements to U.S. generally accepted accounting principles (GAAP). The Form 20-F reconciliation is required by the Securities and Exchange Commission and likely provides previously unavailable information about the listing firm. Adverse rival effects may result if cross-border listings prompt analysts to reassess the competitive balance in favor of the listing firms. We hypothesize that an unfavorable (favorable) response for the rival firm may occur if the new accounting data indicate competitive advantages (disadvantages) for the listing firm or if the market expects greater access to capital for the listing firm to be beneficial. Furthermore, rival firms may benefit if the listings occur when the listing firms are perceived to be operating at peak performance. For example, Dharan and Ikenberry (1995) and Webb (1999) show that firms tend to list during periods of peak performance and may even accelerate their listings so they can satisfy listing requirements before poor performance is revealed. To the extent that the market perceives managerial timing of the listing, rival firms would benefit in anticipation of a competitive advantage.

We use the following variables to test whether competitive effects influence the stock price reaction of the rivals: degree of market segmentation, no prior operating presence in the U.S., and whether the listing is part of privatization efforts.

Degree of Market Segmentation. The degree of market segmentation between the domestic market and the listing market (U.S.) is likely to impact the stock price reaction of rivals to the listing. Listings from segmented markets may have an adverse effect on rivals since the 
listing firm overcomes previous barriers and enjoys greater access to capital. Indeed, a recent study by Lins, Strickland, and Zenner (2000) finds that firms that cross-list are able to access capital markets more frequently following the listing decision. These benefits may give the listing firm a competitive advantage relative to its rivals, causing rival firms to be adversely affected by the listing. Thus, we hypothesize that rival valuation effects will be less favorable (more favorable) for listings originating from segmented (integrated) markets.

No Prior Presence in the U.S. Listing firms with prior operating presence in the U.S. are less likely to generate incremental focus and rival reaction, to the extent that their business presence has already provided sufficient recognition and analysis. In contrast, cross-border listings by firms without prior operating presence in the U.S. should produce greater rival effects. Two competing rival reactions may occur for firms without prior operating presence in the U.S. First, if the increased focus and availability of accounting information benefits the listing firms at the expense of their rivals, the stock prices of the rivals should react unfavorably to the listings. Second, if firms list during a period of peak performance and their performance is expected to deteriorate following the listing (Dharan and Ikenberry (1995) and Webb (1999)), the rivals of cross-border listing firms are expected to benefit. Rivals benefit under this scenario because the market anticipates the future performance of the listing firm to deteriorate, which should cause a reassessment of the competitive balance in favor of the industry rivals.

Privatization Effort. A growing number of cross-border listings occur in the context of privatization efforts. If a cross-border listing is part of a privatization effort, the listing emphasizes to investors the reality of new management and elicits the expectation that the operating efficiency and competitiveness of the listing firm will improve. Megginson, Nash, and Van Randenborgh (1994), Boubakri and Cosset (1998), and D’Souza and Megginson (1999) 
provide strong evidence that privatization improves profitability, efficiency, and dividends. Thus, we hypothesize that industry rivals of cross-border listing firms that are experiencing privatization are likely to be adversely affected by the listing. The adverse implication for rivals arises because the expectation of increased profitability and efficiency of the listing firm may place rivals at a competitive disadvantage.

\section{Information Effects}

Previous intra-industry studies provide evidence that information conveyed by various events affect industry rivals. For example, Szewczyk (1992) argues that security offerings may convey unfavorable information regarding the future prospects for the industry, and Slovin, Sushka, and Bendeck (1991) suggest that going-private transactions may release new information to industry rivals about the future cash flows expected in the industry. Accordingly, cross-border listings may also convey industry-level information. To the extent that benefits accrue to the listing firms due to favorable industry conditions, these benefits should also accrue to their industry rivals. Alternatively, if the listing conveys unfavorable information about the industry as a whole, rivals should be adversely affected by the information conveyed by the listing decision.

We use the following variables to test whether information effects are important in explaining rival valuation effects: whether an equity offering is made in conjunction with the listing, the relative size of the rival firms, whether the listing is the first from a country within a period of time prior to the listing, and whether the listing is the first in the industry within a period of time prior to the listing. 
Equity Offering in Conjunction with Listing. Non-U.S. firms listing in the U.S. may do so as ordinary listings or as ADRs. ${ }^{1}$ In both instances, the firm can choose to issue additional shares in conjunction with the listing. It is well documented that equity issuances convey negative information to the market. Myers and Majluf (1984) argue that managers capitalize on the existence of information asymmetry by issuing overpriced securities. Consequently, investors draw unfavorable inferences about the value of the firm's assets and growth opportunities when new securities are offered. Szewczyk (1992) finds that the negative inference also impacts industry rivals as they experience negative and significant abnormal returns in response to security offerings. Thus, we hypothesize that cross-border listings that occur in conjunction with an offering of additional shares will have an adverse impact on industry rivals.

Relative Size of the Rivals. The impact of the information conveyed by an event may be inversely related to the relative size of the rivals (e.g., Slovin, Sushka, and Bendeck (1991)). This relationship stems from the idea that less information is typically available about relatively small firms compared to relatively large firms. Thus, when a listing occurs, the industry-level information conveyed by the listing is more likely to cause the market to reassess the values of relatively small rivals about which information was relatively scarce. As such, the intra-industry valuation effects due to cross-border listings may be greater for relatively small rival firms. Similarly, the stock prices of relatively large rivals are less likely to react to the cross-border

\footnotetext{
${ }^{1}$ An ordinary listing must take place on a U.S. exchange and requires that the listing firm have the same settlement facilities as those required for U.S. firms. There are also specific reporting and disclosure requirements. There are three levels of ADRs: Level I, Level II, and Level III. Level I ADRs trade on the OTC as "Pink Sheet" issues, whereas Level II and Level III ADRs are listed on an organized exchange. Level II ADRs do not result in additional capital being raised by the firm, while Level III ADRs result in capital being raised by the firm. This study focuses on ordinary listings and Level II and Level III ADRs. Each type of ADR has specific reporting and disclosure requirements (see Foerster and Karolyi (1999) for a detailed discussion of the reporting requirements for ordinary listings and ADRs).
} 
listings, as the embedded information may not contain much incremental value. Thus, we hypothesize that the information effects are greater (smaller) for relatively small (large) rivals.

First Listing from Country. The first listing from a country is likely to result in greater incremental exposure than subsequent listings. For example, Compania de Telefonos de Chile (CTC) listed on the NYSE in 1990 and was the first South American firm to do so in 27 years. ${ }^{2}$ The listing received considerable exposure and CTC officials began a "road show" to canvass potential investors. Thus, we argue that the first listing from a particular country would attract the most attention and therefore, would have the greatest impact on rivals. To the extent that positive (negative) effects accrue to industry rivals, the largest gains (losses) should be associated with the first listing from a particular country. Since both positive and negative information effects for industry rivals may result from listings, the impact of listings with the strongest signals (i.e. first listings from a country) may be difficult to detect due to potentially offsetting effects.

First Listing from Industry. The first cross-border listing that occurs in an industry is likely to convey the most information to the market. To the extent that valuation effects accrue to industry rivals due to industry-level information embedded in the listings, the impact should be strongest for the first listing in the industry. However, since both positive and negative valuation effects for industry rivals may result from the listing, the impact of listings that convey the most information (i.e. first listings from the industry) may be difficult to detect due to potentially offsetting effects.

\footnotetext{
2“Santiago's High Flyers Turn to Wall Street," by L. Crawford, Financial Times (London), July 3, 1990, p. 29.
} 


\section{Sample Selection and Method}

This study focuses on a sample of 269 foreign firms that list on organized U.S. stock exchanges between 1970 and 1999. The sample of cross-border stock listings is obtained from the New York Stock Exchange (NYSE) Research Department and from the Bank of New York, which provides data for listings occurring on the NYSE, American Stock Exchange (ASE), and NASDAQ. To qualify for inclusion in the sample, listings must meet the following criteria:

1) the listing firm has at least one rival in the U.S. with the same four-digit Standard Industrial Classification (SIC) code at the time of the listing with share price data available from the Center for Research in Security Prices (CRSP),

2) the listing represents the first time the foreign firm trades in the U.S. and not a switch from another exchange in the U.S., and

3) there were not multiple listings with the same SIC code on the same day.

Descriptive statistics for the sample of 269 cross-border listings are presented in Table 1. Table 1 shows that most of the listings were made by European firms (147), followed by firms from the Asia/Pacific region (49), North America (32), South/Central America (32), and the Middle East/Africa region (9). Most of the listings occurred in the 1990s (246) with only 4 listings occurring in the 1970s and 19 in the 1980s. Ninety of the listings are by firms from emerging markets, accounting for approximately 33 percent of the listings. Appendix A provides a detailed list of the countries represented in the sample and their classification as emerging or developed, based on information obtained from the International Finance Corporation's Emerging Stock Markets Factbooks.

The event study method is used to measure the average abnormal return (AR) of industry rivals in response to the cross-border listings. In virtually all event studies, there is an 
announcement followed by the actual event. Both points in time may precipitate market reactions. While unambiguous announcement dates may be theoretically superior to listing dates, they are not always available. Foerster and Karolyi (1999) recognize that there are numerous challenges associated with identifying announcement dates for cross-border listings. They note that in some instances, the market anticipates a listing several years in advance even though there is no formal announcement while in other instances the listing is announced but does not subsequently occur. Thus, we use listing dates to conduct the analysis due to inconsistencies in information dissemination, especially among emerging markets. ${ }^{3}$

The ARs for portfolios of U.S. rival firms are calculated using the method employed by Lang and Stulz (1992). The stock return data are collected from the CRSP daily returns file. We form an equally-weighted portfolio of rivals consisting of all rival firms that share the same CRSP four-digit SIC code as the listing firm and have share price data available at the time of the listing. The returns of each rival portfolio are used to estimate the market model parameters, $\hat{\alpha}$ and $\hat{\beta}$, over the 200-day period of $\mathrm{t}_{220}$ to $\mathrm{t}_{-21}$ relative to the listing date. The AR of each rival portfolio, $p$, and for each day, $t$, in the event period $\left(t_{-10}\right.$ to $\left.t_{+10}\right)$ is computed as:

$$
A R_{p t}=R_{p t}-\left(\hat{\alpha}+\hat{\beta} R_{m t}\right)
$$

where $A R_{p t}$ is the abnormal return of the rival portfolio, $R_{p t}$ is the actual daily return of the rival portfolio, and $R_{m t}$ is the actual daily return on the CRSP equally-weighted market index. We compute cumulative daily abnormal returns (CARs) over several windows and follow the method employed by Mikkelson and Partch (1988) to calculate the z-statistics.

\footnotetext{
${ }^{3}$ A preliminary assessment using announcement dates showed that the announcement had no significant impact on the portfolios of rival firms.
} 
The sample of cross-border listings contains representation from 136 distinct industries. The U.S. rival portfolios are constructed from 12,638 firms which have the same 4-digit SIC code as the listing firms. The mean, median, minimum, and maximum number of rivals per portfolio is $47,13,1$, and 380 , respectively.

The ARs are also calculated for portfolios of domestic rivals. We use Compustat's GlobalVantage database to identify the domestic (home country) rivals that share the same SIC code as the listing firm, and to obtain monthly stock prices for these firms and associated domestic market prices. Thus, the reaction of rival portfolios in the domestic market is assessed using a modified equation (1) as follows. Since monthly data are used, $R_{p t}$ is the actual monthly return of the rival portfolio and $R_{m}$ is the actual monthly return on the domestic market. Furthermore, we estimate the market model parameters over a 36 -month period of $t_{-37}$ to $t_{-2}$ relative to the month of the listing, which are subsequently used to generate monthly ARs. Ultimately, 58 domestic rival portfolios with available data comprise the sample and are used to assess the domestic rival reaction to listing in the U.S.

\section{Valuation Effects}

Table 2 presents the valuation effects for the listing firm. The valuation effects are estimated by calculating holding period returns (HPR) based on the percentage change in the stock price on the final day of the holding period compared to the stock price on the initial day of the holding period. We use the same procedure to calculate the HPR for the market as a whole, and then assess the market's HPR relative to the listing firms' HPR. The paired comparison ttest is used to ascertain whether the HPR of the listing firms are significantly different from the HPR of the market. Since the firms are listed in the U.S. market, they should be affected by 
many of the same factors that drive the U.S. market. Thus, the analysis is conducted using both the U.S. market and the corresponding local market as benchmarks.

Table 2, Panel A shows the results relative to the U.S. market. Listing firms gain an average of 0.2323 percent on the list date, where the stock price on the initial day of this holding period is assumed to be the reported offer price. ${ }^{4}$ The average listing firm HPR for the list date (0.02323) is significantly higher than the mean HPR for the market as a whole over the same period $(-0.0009$ percent). The mean HPR for the listing firms over the event period is 0.2274 percent and -0.0003 percent for the market, which again are significantly different at the one percent level. In the immediate post-listing periods $\left(t_{+1}\right.$ to $\left.t_{+10}\right)$ and $\left(t_{+10}\right.$ to $\left.t_{+59}\right)$, the listing firms' HPR is not significantly different from the market's HPR. However, three months following the listings, the nine-month holding period $\left(t_{+59}\right.$ to $\left.t_{+249}\right)$ reveals that the listing firms significantly underperform the market. This degradation in performance subsequent to listing is consistent with the findings of Dharan and Ikenberry (1995) and Webb (1999) that listing firms tend to list during periods of peak performance and experience performance degradation subsequent to the listing. The evidence is also consistent with the findings of Alexander, Eun, and Janakiramanan (1988) and Foerster and Karolyi (1993) who find that listing firms tend to underperform in the post-listing period.

Panel B shows the results based on the corresponding local market benchmark. The listing firms gain an average of 0.2684 percent on the list date, which is considerably higher than the market as a whole ( 0.0014 percent). Similar results are observed in the event period. In the post-event periods, differences between the mean holding period returns for the listing firms and

\footnotetext{
${ }^{4}$ The offer prices are gathered from Moody's International manuals and Lexis-Nexis.
} 
the local market are not statistically significant, although the size of the returns are quite similar to those reported in Panel A.

The valuation effects for the U.S. rivals of the listing firms are shown in Table 3, Panel A. The U.S. rivals experience an average pre-listing return $(-10,-2)$ of 0.2830 percent, which is not statistically significant. The day before the listing (-1) the rival firms gain an average of 0.3219 percent, which is significant at the one percent level. Over the three-day window $(-1$, +1 ), rivals gain an average of 0.1717 percent, which is significant at the ten percent level. Overall, the results indicate that U.S. rivals respond favorably to cross-border listings. The positive reaction may be attributable to competitive effects, information effects, or both. Since positive returns may be explained by both hypotheses, additional analysis is necessary to further understand the importance of both effects. We explore these arguments in Section VI.

The valuation effects for the domestic rivals are shown in Panel B of Table 3. This analysis is conducted using monthly returns given the difficulty of obtaining daily stock price data for rival firms in the domestic markets. The results show that the reaction of the 58 domestic rival portfolios in the month of the listing is not significant, on average. The reaction of the domestic rivals in the month preceding and the month following the listing are also insignificant. This analysis indicates that the domestic market rivals are not significantly impacted by the decision of their competitors to list overseas.

\section{Cross-Sectional Model and Results}

A key contribution of this study is the examination of the importance of competitive and information effects in explaining the differential reaction of U.S. rivals to cross-border listings. This section presents the regression model, defines the explanatory variables, and reports the results. 
The following regression model is used to assess the importance of the variables in explaining the differential market reaction of U.S. rivals to cross-border listings:

$$
\begin{aligned}
\text { RIVCAR }_{j}= & \alpha_{0}+\beta_{0} \text { DEVEL }_{j}+\beta_{1} \text { NOPRIOR }_{j}+\beta_{2} \text { PRIVATE }_{j}+\beta_{3} \text { OFFERING }_{j} \\
& +\beta_{4} \text { RELSIZE }_{j}+\beta_{5} \text { CTRY1ST }_{j}+\beta_{6} \text { INDY1ST }_{j}+\beta_{7} \text { EXCHG }_{j}+e_{j}
\end{aligned}
$$

\begin{tabular}{|c|c|}
\hline $\begin{array}{l}\operatorname{VACAR}_{\mathrm{j}} \\
\text { EVEL }_{\mathrm{j}}\end{array}$ & $\begin{array}{l}=\text { three-day CAR }(-1,1) \text { of U.S. rival portfolio } \mathrm{j} \text { in response to the listing } \\
=1 \text { if the listing originates from a developed country; } 0 \text { otherwise. The } \\
\text { classification is based on the IFC scheme shown in the Appendix. }\end{array}$ \\
\hline OPRIOR $_{\mathrm{j}}$ & $\begin{array}{l}=1 \text { if the listing firm did not operate in the U.S. prior to the listing, and } \\
0 \text { otherwise; }\end{array}$ \\
\hline IVATE $_{j}$ & $=1$ if the listing is part of privatization efforts, and 0 otherwise ${ }^{6}$ \\
\hline FERING & $\begin{array}{l}=1 \text { for listings that occur in conjunction with an equity offering, and } 0 \\
\text { otherwise; } ;\end{array}$ \\
\hline ZLSIZE $_{j}$ & $\begin{array}{l}=1 \text { if the listing firm's market value is greater than the mean market } \\
\text { value of rivals, and } 0 \text { otherwise }{ }^{8}\end{array}$ \\
\hline $\mathrm{RY}_{\mathrm{ST}} \mathrm{T}_{\mathrm{j}}$ & $\begin{array}{l}=1 \text { if the listing is the first from a country within one year prior to the } \\
\text { current listing, and } 0 \text { otherwise; }\end{array}$ \\
\hline $1 \mathrm{ST}_{\mathrm{j}}$ & $\begin{array}{l}=1 \text { if the listing is the first in the industry within one year prior to the } \\
\text { current listing, and } 0 \text { otherwise; }\end{array}$ \\
\hline & $\begin{array}{l}=1 \text { if the listing occurs on the NYSE, and } 0 \text { otherwise; } \\
=\text { random error term. }\end{array}$ \\
\hline
\end{tabular}

where:

Table 4 provides descriptive statistics for the cross-sectional variables. Sixty-seven percent of the listings originate in developed countries, 44 percent of the firms have no prior presence in the U.S., 12 percent of the listings are part of a privatization effort, 73 percent of the listings are made in conjunction with an equity offering, and 18 percent of the listing firms have rivals that can be classified as relatively small. Nineteen percent of the listings are the first from

\footnotetext{
${ }^{5}$ Moody's International manuals are used to determine if the firm had a subsidiary or a significant operating presence in the U.S. In some instances, Lexis-Nexis articles also indicated whether or not firms had prior presence in the U.S.

${ }^{6} \mathrm{~A}$ listing is classified as part of a privatization effort based on information provided in Moody's International manuals and Lexis-Nexis articles.

${ }^{7}$ Data for this variable are obtained from Moody's International manuals and Lexis Nexis articles.

${ }^{8}$ Capitalization data are obtained from CRSP at the end of the previous period. Capitalization is calculated as the number of shares outstanding at the end of the previous period times the price on that date.
} 
a particular country within a one-year period of time prior to the listing, and 32 percent of the listings are the first to occur in the industry within a one-year period of the listing. The majority (61 percent) of the listings occur on the NYSE.

The results obtained from the cross-sectional model are shown in Table 5. The variables have been standardized by the mean square error of the estimation model to control for heteroskedasticity. The cross-sectional analysis is based on a subsample of 172 firms for which data are available for all the cross-sectional variables.

\section{Competitive Effects}

There are three variables associated with the competitive effects of cross-border listings that have been hypothesized to impact U.S. rivals. The coefficient estimate on DEVEL is negative and significant at the 5 percent level $(t=-1.96)$, suggesting that listings from developed markets have a more adverse effect on rivals than listings from emerging markets. This result is somewhat surprising, given the hypothesis that listings from segmented markets should generate competitive effects. The result may be attributable to the fact that classifying markets as emerging or developed is inherently ambiguous (e.g., Miller, 1999). Thus, we also used the correlation between the U.S. market returns and the listing market returns (MKTCORR) as an alternative proxy for market segmentation. In the interest of brevity, these results are not tabulated. However, the coefficient estimate on this variable MKTCORR was positive $(0.0696)$ and significant at the five percent level $(t=2.00)$. This result suggests that the higher (lower) the correlation between the listing and domestic markets the more (less) favorable the reaction of rival firms. Use of the MKTCORR proxy indicates that cross-border listings from segmented markets may help the listing firms overcome previous barriers giving the listing firms greater competitive advantage. However, caution must be exercised in using this variable as a proxy 
since a low correlation may not indicate segmentation and vice versa. For example, the correlation between the U.S. and Japanese markets is low even though studies show that these two markets are integrated. Similarly, two segmented markets may have a high correlation because they share a similar industrial structure. ${ }^{9}$

The coefficient estimate on NOPRIOR is positive (0.0123) and statistically significant at the ten percent level $(t=1.76)$. It is possible that the relatively low significance level is due to the competing effects discussed in the hypothesis section. This finding indicates that more favorable effects accrue to rivals from cross-border listings by firms without prior operating presence in the U.S. and these favorable effects dominate any unfavorable effects. Given the evidence in Table 2 that firms tend to list during periods of peak performance and experience deteriorating performance subsequent to listing (see also Dharan and Ikenberry (1995) and Webb (1999)), listings by firms without prior operating presence in the U.S. appear to trigger a reassessment of the competitive balance in favor of the rivals.

The coefficient estimate on PRIVATE is not significant, suggesting that U.S. rivals are largely unaffected by foreign firms listing in the U.S. as part of their privatization efforts. Information Effects

There are five variables associated with the information effects of cross-border listings that have been hypothesized to impact U.S. rivals. The coefficient estimate on OFFERING $(-0.0195)$ is significant at the five percent level $(t=-2.32)$. This finding suggests that crossborder listings with an equity-raising element convey unfavorable information at the industrylevel. As we hypothesized, cross-border listings that raise equity may indicate that the listing firm and industry in general are overvalued. This result is consistent with Szewczyk's (1992) evidence that industry rivals are adversely affected by security offerings.

\footnotetext{
${ }^{9} \mathrm{We}$ thank an anonymous reviewer for providing this clarification.
} 
INDY1ST has a positive coefficient estimate (0.0327), suggesting that the first listing from an industry has a significant positive impact on rivals $(t=4.45)$. This finding is consistent with the evidence provided by Freeman and Tse (1992) that the first quarterly announcement in the industry generates the greater intra-industry effects. A positive sign on the coefficient is consistent with the notion that the initial listing within an industry conveys greater favorable information about the future prospects for the industry than subsequent listings.

The coefficient estimates for RELSIZE, CTRY1ST, and EXCH are not significant. Overall, the adjusted $\mathrm{R}^{2}$ for the model is 0.1495 and the F-value is 4.76 , significant at the one percent level.

Taken collectively, the cross-sectional results suggest that both competitive effects and information effects play a significant role in explaining the variation in returns to U.S. rivals of cross-border listings. Regarding the competitive effects, we find that U.S. rival returns are lower for listings originating in developed countries, and greater for listings by firms without prior operating presence in the U.S. Consistent with the information effects hypothesis, we find that the returns to U.S. rivals are lower when stock offerings are made in conjunction with the listing and are higher for initial listings from a particular industry.

\section{CONCLUSIONS}

We examine a sample of 269 cross-border listings occurring on U.S. stock exchanges between 1970 and 1999 to estimate the valuation effects of the listings on rivals in the U.S. and rivals in the domestic market of the listing firm. Previous studies have documented significant returns to foreign firms listing in the U.S., we argue that cross-border listings may also have a significant impact on rivals because of competitive and/or information effects. 
The results indicate that U.S. rivals experience positive and significant valuation effects in response to the cross-border listings, while domestic market rivals do not experience significant effects. The findings are consistent with the hypothesis that cross-border listings result in a reevaluation of the competitive balance in the industry. Specifically, U.S. rival abnormal returns are lower for listings from developed countries and higher for listings by firms without prior U.S. operating presence. Our results are also consistent with the hypothesis that valuable industry-level information is conveyed by cross-border listings. Specifically, the returns to U.S. rivals are lower when stock offerings are made in conjunction with the listing and are higher for the first listing from a particular industry. Thus, both competitive and information effects are important in explaining the cross-sectional variation in the response by U.S. industry rivals to cross-border listings. 


\section{REFERENCES}

Alexander, F., C. Eun, and S. Janakiramanan, 1988, International listings and stock returns: Some empirical evidence, Journal of Financial and Quantitative Analysis 23, 135-152.

Bekaert, G. and C.R. Harvey, 1997, Emerging equity market volatility, Journal of Financial Economics 43, 29-77.

Boubakri, N. and J.C. Cosset, 1998, The financial and operating performance of newly privatized firms: evidence from developing countries, Journal of Finance 53, 1081-1110.

Dharan, B.G. and D.L. Ikenberry, 1995, The long-run negative drift of post-listing stock returns, Journal of Finance 50, 1547-1574.

D'Souza, J. and W.L. Megginson, 1999, The financial and operating performance of privatized firms during the 1990s, Journal of Finance 54, 1397-1438.

Foerster, R.F. and G.A. Karolyi, 1993, International listings of stocks: The case of Canada and the U.S., Journal of International Business Studies 24, 763-784.

Foerster, R.F. and G. A. Karolyi, 1999, The effects of market segmentation and investor recognition on asset prices: Evidence from foreign stocks listing in the U.S., Journal of Finance 54, 981-1013.

Freeman, R. and S. Tse, 1992, An earnings prediction approach to examining intercompany information transfers, Journal of Accounting and Economics 15, 509-523.

Karolyi, G.A., 1998, Why do companies list shares abroad?: A survey of the evidence and its managerial implications, in Financial Markets, Institutions \& Instruments (Blackwell Publishers, Malden, NJ).

Jayaram, N., K. Shastri, and K, Tandon, 1993, The impact of international cross listings on risk and return: Evidence from American depositary receipts, Journal of Banking and Finance $17,91-103$.

Lang, L. and R.M. Stulz, 1992, Contagion and competitive intra-industry effects of bankruptcy announcements, Journal of Financial Economics 32, 45-60.

Lins, K., D. Strickland, and M. Zenner, 2000, Do non-US firms issue equity on US stock exchanges to relax capital constraints?, working paper.

Megginson, W.L., R.C. Nash, and M. van Randenborgh, 1994, The financial and operating performance of newly privatized firms: an international empirical analysis, Journal of Finance 49, 403-452. 
Merton, R.C., 1987, A simple model of capital market equilibrium with incomplete information, Journal of Finance 42, 483-510.

Mikkelson, W., and M. Partch, 1988, Withdrawn security offerings, Journal of Financial and Quantitative Analysis 23, 119-34.

Miller, D.P., 1999, The market reaction to international cross-listings: evidence from depositary receipts, Journal of Financial Economics 51, 103-123.

Myers, S.C. and N.S. Majluf, 1984, Corporate financing and investment decisions when firms have information that investors do not have, Journal of Financial Economics 13, 187221.

Slovin, M.B., M. Sushka and Y. Bendeck, 1991, The intra-industry effects of going private transactions, Journal of Finance 46, 1537-1550.

Slovin, M.B, M. E. Sushka and J.A. Polonchek, 1992, Informational externalities of seasoned equity issues, Journal of Financial Economics 32, 87-101.

Switzer, L., 1997, Shareholder wealth effects of international listings: New Evidence for Canadian stocks listed on the NYSE, Amex and Nasdaq, 1985-96, Concordia University working paper.

Szewczyk, S., 1992, The intra-industry transfer of information inferred from announcements of corporate security offerings, Journal of Finance, 47, 1935-1945.

Webb, G.P., 1999, Evidence of managerial timing: The case of exchange listings, Journal of Financial Research 22, 247-263. 
TABLE 1. The Sample Distribution by Region and Year for Cross-Border Listings in the U.S.

\begin{tabular}{|c|c|c|c|c|c|c|c|}
\hline Year(s) & $\begin{array}{l}\text { West/East } \\
\text { Europe }\end{array}$ & $\begin{array}{l}\text { North } \\
\text { America }\end{array}$ & $\begin{array}{l}\text { South/Central } \\
\text { America }\end{array}$ & $\begin{array}{l}\text { Asia/Pacific } \\
\text { Rim }\end{array}$ & $\begin{array}{l}\text { Middle } \\
\text { East/Africa }\end{array}$ & $\begin{array}{l}\text { Emerging } \\
\text { Markets }\end{array}$ & $\begin{array}{l}\text { All } \\
\text { Regions }\end{array}$ \\
\hline $\begin{array}{l}1970- \\
1999\end{array}$ & 147 & 32 & 32 & 49 & 9 & 90 & 269 \\
\hline $\begin{array}{l}1970- \\
1979\end{array}$ & 0 & 0 & 0 & 4 & 0 & 0 & 4 \\
\hline $\begin{array}{l}1980- \\
1989\end{array}$ & 18 & 0 & 0 & 1 & 0 & 0 & 19 \\
\hline 1990 & 4 & 2 & 1 & 1 & 1 & 2 & 9 \\
\hline 1991 & 4 & 1 & 0 & 3 & 0 & 1 & 8 \\
\hline 1992 & 7 & 2 & 3 & 1 & 1 & 6 & 14 \\
\hline 1993 & 15 & 9 & 8 & 4 & 1 & 19 & 37 \\
\hline 1994 & 8 & 7 & 12 & 8 & 0 & 24 & 35 \\
\hline 1995 & 10 & 4 & 1 & 4 & 1 & 5 & 20 \\
\hline 1996 & 25 & 4 & 6 & 9 & 2 & 14 & 46 \\
\hline 1997 & 17 & 0 & 1 & 3 & 2 & 3 & 23 \\
\hline 1998 & 19 & 2 & 0 & 1 & 1 & 8 & 23 \\
\hline 1999 & 20 & 1 & 0 & 10 & 0 & 8 & 31 \\
\hline
\end{tabular}

${ }^{1}$ Excluding the U.S.

Note: This table shows the distribution of listings by region and year for the sample of 269 cross-border listings occurring between 1970 and 1999. The emerging markets are classified according to information obtained from the International Finance Corporation's Emerging Stock Markets Factbooks. Appendix A lists the countries. 
TABLE 2. The Valuation Effects for Foreign Firms Listing in the U.S.

\begin{tabular}{|c|c|c|c|c|}
\hline Holding Periods & $\mathrm{N}$ & $\begin{array}{c}\text { Mean } \\
\text { Listing Firm } \\
\text { HPR \% }\end{array}$ & $\begin{array}{l}\text { Market } \\
\text { HPR \% }\end{array}$ & $\begin{array}{c}\text { Paired } \\
\text { t-test }\end{array}$ \\
\hline
\end{tabular}

Panel A: U.S. Market HPRs

List date ${ }^{\mathrm{a}}$

Event period ${ }^{\mathrm{a}}$

Post-event period $\left(t_{+1}\right.$ to $\left.t_{+10}\right)$

Post-event period $\left(t_{+10}\right.$ to $\left.t_{+59}\right)$

Post-event period $\left(t_{+59}\right.$ to $\left.t_{+249}\right)$
187

187

187

176

161
0.2323

0.2274

0.0061

0.0352

0.0423
$-0.0009$

$-0.0003$

0.0001

0.0215

0.1278
$2.73^{* * * *}$

$2.66^{* * *}$

0.01

0.73

$-2.22^{* *}$

Panel B: Local Market HPRs

\begin{abstract}
List date ${ }^{\mathrm{a}}$
Event period ${ }^{\mathrm{a}}$

Post-event period $\left(t_{+1}\right.$ to $\left.t_{+10}\right)$

Post-event period $\left(t_{+10}\right.$ to $\left.t_{+59}\right)$
\end{abstract}

Post-event period $\left(t_{+59}\right.$ to $\left.t_{+249}\right)$
154

154

154

144

132
0.2684

0.2593

0.0089

0.0271

0.0289
0.0014

0.0005

0.0096

0.0235

0.0873
$2.59^{* * *}$

$2.51^{\text {**** }}$

$-0.07$

0.18

Notes: This table presents the holding period returns (HPR) for foreign firms listing on U.S. stock exchanges between 1970 to 1999 that have offer prices available. HPRs for the listing firms are calculated as the percentage change in the U.S. stock price relative to the reported offer price over the various holding periods. As shown in Panel A, the sample size is reduced to 187 from 269 because offer prices were not always reported in Moody's International manuals or Lexis-Nexis. As shown in Panel B, the sample size is further reduced to 154 because the Dow Jones market returns were not always available.

${ }^{\text {a }}$ The HPR on the list date is calculated as the difference (in percent) between the closing price on the list date and the initial offer price while the HPR for the event period is calculated as the difference (in percent) between the closing price on day $\mathrm{t}+1$ and the initial offer price.

***Significant at the 1 percent level.

**Significant at the 5 percent level. 


\section{TABLE 3. The Valuation Effects for U.S. And Domestic Market Industry Rivals in Response to Cross-Border Listings in the U.S.}

Examination period

$\mathrm{CAR} \%$

Z-statistic

$\mathrm{N} \quad \%$ Positive

Panel A: U.S. rival portfolio response surrounding listing dates

$\begin{array}{llrcrr}\text { Pre-event period } & {[-10,-2]} & 0.2830 & 1.35 & 269 & 53 \\ \text { Day }-1 & & 0.3219 & 2.96^{* * *} & 269 & 53 \\ \text { Day 0 } & & -0.0886 & -0.92 & 269 & 47 \\ \text { Day }+1 & -0.0616 & 0.94 & 269 & 46 \\ \text { Event period } \quad[-1,+1] & 0.1717 & 1.72^{*} & 269 & 50 \\ \text { Post-event period }[+2,+10] & -0.4271 & -0.03 & 269 & 43\end{array}$

Panel B: Domestic rival portfolio response surrounding listing dates

$\begin{array}{lrrrr}\text { Month -1 } & -0.1633 & -0.10 & 58 & 41 \\ \text { Month 0 } & -1.2186 & -1.10 & 58 & 41 \\ \text { Month }+1 & 0.1126 & 0.36 & 58 & 45\end{array}$

Notes: This table presents the mean cumulative abnormal returns (CARs) for U.S. and domestic rivals of the listing firms. U.S. rival portfolios contain all U.S. rival firms and domestic rival portfolios contain all domestic rival firms with the same SIC code as the listing firm that have available stock price data at the time of the listing. The sample period ranges from 1970 to 1999 . Abnormal returns are calculated as the difference between the actual returns and expected returns. U.S. rival expected returns are generated using the market model, which is estimated using daily returns from the period $t_{-220}$ to $t-21$ where $t_{0}$ is the listing date. Domestic rival expected returns are generated using the market model, which is estimated with monthly returns from the period $t_{-37}$ to $t_{-2}$, where $t_{0}$ is the month of the listing.

***Significant at the 1 percent level.

* Significant at the 10 percent level. 
TABLE 4. Summary of the Independent Variables Used in the Cross-Sectional Model.

\begin{tabular}{|c|c|}
\hline Variable & Summary Statistics \\
\hline \multicolumn{2}{|l|}{ Competitive Effects: } \\
\hline \multicolumn{2}{|l|}{ DEVEL } \\
\hline Listing From Developed Country & $179(67 \%)$ \\
\hline Listing from Emerging Country & $90(33 \%)$ \\
\hline \multicolumn{2}{|l|}{ NOPRIOR } \\
\hline No Prior U.S. Presence & $108(44 \%)$ \\
\hline Prior U.S. Presence & $135(56 \%)$ \\
\hline \multicolumn{2}{|l|}{ PRIVATE } \\
\hline Part of Privatization Effort & $31(12 \%)$ \\
\hline Not Part of Privatization Effort & $222(88 \%)$ \\
\hline \multicolumn{2}{|l|}{ Information Effects: } \\
\hline \multicolumn{2}{|l|}{ OFFERING } \\
\hline Listing is Accompanied by an Offering & $174(73 \%)$ \\
\hline Listing is not Accompanied by an Offering & $64(27 \%)$ \\
\hline \multicolumn{2}{|l|}{ RELSIZE } \\
\hline Relatively Small Rivals & $47(18 \%)$ \\
\hline Relatively Large Rivals & $208(82 \%)$ \\
\hline \multicolumn{2}{|l|}{ CTRY1ST } \\
\hline First Listing from Country within 1 Year & $47(19 \%)$ \\
\hline Not First Listing from Country within 1 Year & $202(81 \%)$ \\
\hline \multicolumn{2}{|l|}{ INDY1ST } \\
\hline First Listing from Industry within 1 Year & $71(32 \%)$ \\
\hline Not First Listing from Industry within 1 Year & $154(68 \%)$ \\
\hline \multicolumn{2}{|l|}{ EXCHG } \\
\hline Listing occurs on NYSE & $164(61 \%)$ \\
\hline Listing does not occur on NYSE & $105(39 \%)$ \\
\hline
\end{tabular}

Notes: This table shows summary statistics for the independent variables. DEVEL is equal to 1 if the listing originates from a developed country, 0 otherwise; NOPRIOR is equal to 1 if the listing firm did not operate in the U.S. prior to the listing, 0 otherwise; PRIVATE is equal to 1 if the listing firm is experiencing privatization, 0 otherwise; OFFERING is equal to 1 if the listing is accompanied by an equity offering, 0 otherwise; RELSIZE is equal to 1 if the listing firm's market value is greater than the mean market value of rivals, 0 otherwise; CTRY1ST is equal to 1 if the listing is the first listing from a country within a 1 year period prior to the current listing, 0 otherwise; INDY1ST is equal to 1 if the listing is the first listing from an industry within 1 year, 0 otherwise; and EXCHG is equal to 1 if the listing occurs on the NYSE, 0 otherwise. 


\section{TABLE 5. Cross-Sectional Tests of Competitive and Information Effects.}

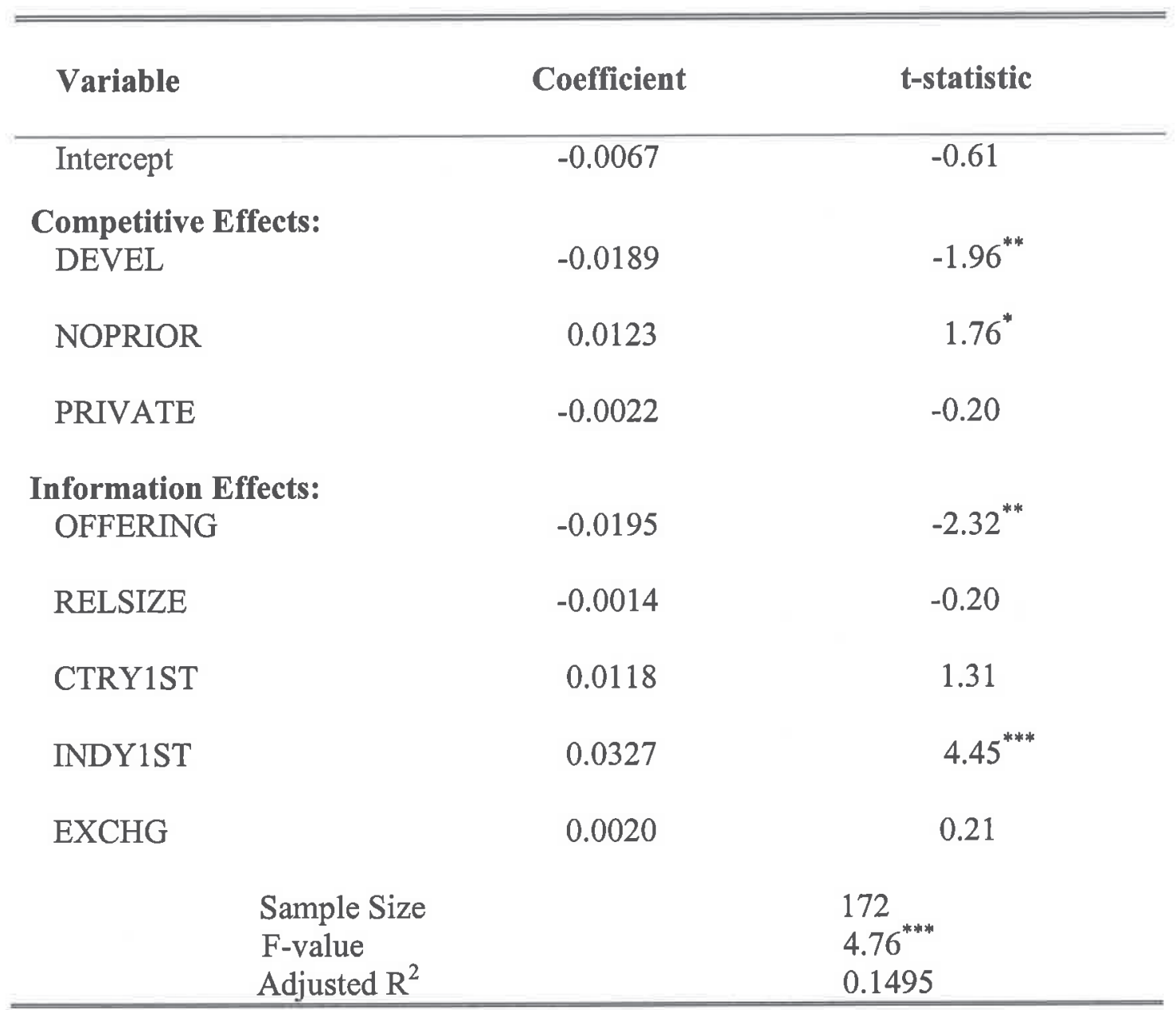

Notes: This table shows the results of estimating the cross-sectional model. The dependent variable is the U.S. rival portfolio 3-day CAR. DEVEL is equal to 1 if the listing originates from a developed country, 0 otherwise; NOPRIOR is equal to 1 if the listing firm did not operate in the U.S. prior to the listing, 0 otherwise; PRIVATE is equal to 1 if the listing firm is experiencing privatization, 0 otherwise; OFFERING is equal to 1 if the listing is accompanied by an equity offering, 0 otherwise; RELSIZE is equal to 1 if the listing firm's market value is greater than the mean market value of rivals, 0 otherwise; CTRY1ST is equal to 1 if the listing is the first listing from a country within a 1 year period prior to the current listing, 0 otherwise; INDY1ST is equal to 1 if first listing from industry within 1 year, 0 otherwise; and EXCHG is equal to 1 if the listing occurs on the NYSE, 0 otherwise.

***Significant at the 1 percent level.

**Significant at the 5 percent level. 


\section{APPENDIX A. Countries Represented in the Sample of Cross-Border Listings.}

\begin{tabular}{ll} 
Emerging Countries & Developed Countries \\
\hline Argentina & Australia \\
Bahamas & Belgium \\
Brazil & Canada \\
Chile & Denmark \\
China & Finland \\
Dominican Republic & France \\
Greece & Germany \\
India & Hong Kong \\
Indonesia & Ireland \\
Israel & Italy \\
Liberia & Japan \\
Mexico & Luxembourg \\
Panama & Netherlands \\
Peru & New Zealand \\
Poland & Norway \\
Portugal & Singapore \\
Russia & Spain \\
South Africa & Sweden \\
South Korea & Switzerland \\
Taiwan & United Kingdom \\
Venezuela &
\end{tabular}

Note: This appendix provides a list of the countries represented in the sample and their classification as emerging or developed, based on information obtained from the International Finance Corporation's Emerging Stock Markets Factbooks. 